\title{
Bankacılıkta Dijital Dönüşümle Değişen Müşteri Deneyimi: Müşteri Sadakati, Memnuniyeti ve Tavsiye Eğilimine Yansımaları*
}

\author{
Samet AYDIN ${ }^{* *} \quad$ Ecem ONAYLI***
}

\begin{abstract}
$\ddot{O} Z$
Bilişim teknolojilerinde yaşanan ilerlemeler, her sektörde olduğu gibi bankacılıkta da dijital dönüşümü zorunlu kılmış ve sektörün iş yapış biçiminde, özellikle de pazarlama araçlarında büyük değişimler meydana getirmiştir. İnternet kullanımının ve akıllı cihazların yaygınlaşması ile bankalar dijital bankacılık uygulamalarını birbiri ardına tanıtmış ve artık bu kanallar müşteriler için banka şubelerine benzer bir konuma erişmiştir.

Bu çalışma, bankacılık sektöründe yaşanan dijital dönüşüm ile değişen müşteri deneyiminin müşsterilerin sadakat, tatmin ve tavsiye eğilimi gibi tutumları üzerindeki yansımalarını incelemektedir. Araştırma kapsamında veri dijital bankacılık müşterilerinden anket yöntemi ile elde edilmiştir (n=364). PLS-SEM yöntemi ile gerçekleştirilen analizler sonucunda müşteri deneyimi alt boyutlarından kullanışlılık ve kullanım kolaylığının müşteri tatmini ve müşteri sadakati üzerinde olumlu ve anlaml etkisi tespit edilmiştir. Hız, güvenlik, müşteri desteği ve bilgi içeriği alt boyutlarının ise müşsteriler nezdinde fark yaratmadı̆̆ uygulamaları ile rekabet avantajı sağlamaları için kullanışlılık ve kullanım kolaylığı öğelerine ağırlık vermeleri gerektiği belirlenmiştir.
\end{abstract}

Anahtar Kelimeler: Dijital Bankacılık, Müşteri Deneyimi, Müşteri Sadakati, Müşteri Tatmini, Tavsiye Ĕ̈ilimi

JEL Sinıflandirmast: M31, G21

\section{Customer Experience within Digital Transformation in Banking: The Reflections on Customer Loyalty, Satisfaction, and Referral}

\begin{abstract}
Advances in IT required digital transformation to be embraced by banking industry, as in others, and caused great changes in the business, especially in marketing tools. With the widespread use of the Internet and smart devices, banks introduced digital banking applications one after another, and these channels have now reached a position similar to bank branches for customers.

This study examines the reflections of the digital transformation in the banking sector and the changing customer experience on the attitudes of customers, such as loyalty, satisfaction, and referral. Within the scope of the research, the data were obtained from digital banking customers by survey method $(n=364)$. As a result of the analyzes carried out with the PLS-SEM method, "usability" and "ease of use" were found to have significant and positive effects upon customer satisfaction and customer loyalty. In contrast, other sub-dimensions of customer experience; speed, security, customer
\end{abstract}

\footnotetext{
* Bu çalışma, Dr. Öğr. Üyesi Samet Aydın danışmanlığında yürütülen Bahçeşehir Üniversitesi Sosyal Bilimler Enstitüsü öğrencisi Ecem Onaylı'nın aynı başlıklı Yüksek Lisans tezinden üretilmiştir.

*** Dr. Öğr. Üyesi, Maltepe Üniversitesi İşletme ve Yönetim Bilimleri Fakültesi Uluslararası Ticaret ve Lojistik (İng.) Bölümü, sametaydin@maltepe.edu.tr ORCID Bilgisi: 0000-0003-2275-4682

*** Lisansüstü Öğrencisi, Bahçeşehir Üniversitesi Sosyal Bilimler Enstitüsü İşletme Yüksek Lisans Programı, dalkilicecem@gmail.com ORCID Bilgisi: 0000-0003-1699-9683
}

(Makale Gönderim Tarihi: 02.06.2020 / Yayına Kabul Tarihi:03.11.2020) 
support and information content did not make any difference to the customers. The results revealed that regarding digital applications banks need to focus on usefulness and ease of use in order to become competitive in the market.

Key Words: Digital Banking, Customer Experience, Customer Satisfaction, Customer Loyalty, Intention to Recommend

JEL Classification: M31, G21

\section{GíRIS}

Dijital teknolojilerin hızlı gelişimi bütün endüstrilerde işletmeleri kendi durumlarını ve geleceklerini değerlendirmeye, pazar koşullarında meydana gelen değişimi anlamaya ve temel stratejilerini güncellemeye sevk etmiştir. Bankacılık sektöründe öncelikle içe dönük operasyonel süreçleri iyileştirme amaciyla kullanımı yaygınlaşan teknolojiler, sonradan müşterilere sunulan ürün ve hizmetlerin yeniden tasarlanması, müşterilere erişim ve dahası yeni müşteri kazanımı çabalarına doğru genişlemiştir. Dijital teknolojilerin müşteriler tarafından hızlı bir şekilde benimsenmesi tüm işletmeler için dijital dönüşümü kaçınılmaz bir yolculuk haline getirmiştir.

Pazarlama açısından değerlendirilecek olunur ise bilişim teknolojilerinin bankacılık sektöründeki pazarlama araçlarında büyük değişimler yarattığı açıkça gözlenebilmektedir. İnternet tabanlı yeni ürünler ve/veya yeni kanallar ilk başlarda yüksek eğitim ve genç yaş gibi sınırlı pazar bölümlerine hitap edecek şekilde programlanmış ve sunulmuş olsa da akı1ll cihazların ve geniş bant/mobil internet erişiminin tüm müşteri grupları tarafindan hızlı bir şekilde benimsenmesi nedeniyle bankalar oldukça yoğun bir şekilde dijital kanallardan hizmet vermeye yönelmiştir. Böylece her bir bilgisayar ve akıllı telefon, müşteriler için birer banka şubesi haline gelmeye başlamıştır.

Değişen bu hizmet ortamı sayesinde bankacıllk sektöründe müşteri deneyimi kavramı yeni baştan ele alınmış ve bankalar, müşterilerinin finansal işlemlerinde dijital çözüm ortağ 1 olarak hareket ederek müşterilerine en iyi deneyimi yaşatmak amacıyla sürekli bir iyileştirme çabası içine girmiştir. $\mathrm{Bu}$ çalışmada, bankacılık sektöründe dijital dönüşümün etkisiyle değişen müşteri deneyiminin mevcut müşterilerin elde tutulması ve yeni müşteri kazanımı için önemli hususlar olan müşteri sadakati, müşteri tatmini ve müşterilerin tavsiye eğilimleri üzerindeki etkileri incelenmiştir. Bankacilıkta geçmişte müşteri ile tek temas noktası olan şubelerde işlem yaptırabilmek için uzun süreler sıra beklenmesi, formaliteler, birden fazla birim ile muhatap olma gibi müşteri memnuniyetsizliğine neden olan etkenler dijital bankacılık ile en aza indirilmeye çalışılmaktadır. Dijital uygulamalar her ne kadar hızlı ve kolay süreçler getiriyor olsa da müşteri ve banka çalışanı arasındaki birebir insan ilişkisini azaltmaktadır. Müşteri deneyimindeki bu değişimin ve müşteri tutumlarına etkilerinin anlaşılması, bankacılık gibi yüksek rekabetin olduğu bir pazarda işletmeler için önemli bir kazanım olacaktır.

\section{LITERATÜR INCELEMESI}

\section{A. Türkiye Bankacılık Sektöründe Dijital Dönüşüm}

Teknolojik gelişmelerin hızla ilerlemesiyle birlikte internet teknolojisi de önemli bir ivme kazanmıştır. İnternet teknolojisinin önemli kullanım alanlarından 
biri de bankacılık sektörüdür. Son yıllarda bankacılık ürünlerinde çok hızlı bir değişim gözlenmektedir ve yeni ürünler birbiri ardına duyurulmaktadır (Aksoy, 2007).

Bilgi ve iletişim teknolojilerindeki hızlı gelişmeler sonucunda bu teknolojiler ticari hayatta da kullanılmaya başlanmış, ticari faaliyetler için gerekli bilgi ve belgeler elektronik ortama aktarılarak işlemler bu ortamda yapılmaya başlanmıştır. Tüm bu gelişmeler elektronik ticaretin yayılmasını kolaylaştırmıştır (Korkmaz ve Gövdeli, 2005). Bu çerçevede, bankacıllk sektöründe günün en ileri teknolojisi kullanılarak bireylere ve işletmelere her türlü işlem ve bilgi aktarımı sunulmaya başlanmıştır. Böylece, bankacılık sektöründe "dijital bankacılık" dönemi açılmıştır.

Şubesiz bankacilık olarak da adlandırılan dijital bankacılık, genel bir tanımlama ile bankacılık ürün ve hizmetlerinin dijital kanallar yoluyla sağlanmasıdır (Takan, 2001). Benzer şekilde Hinson, Osarenkhoe ve Okoe (2013) dijital bankacılık kavramını, bankacılık faaliyetlerinin sanal platformlar üzerinden gerçekleştirilmesi olarak tanımlamışlardır. Savaş ve diğerleri (2014) ise dijital bankacıllı̆̆ , bankacılık hizmetlerinin şube ve personel gerektirmeden müşterilere ulaştırılması olarak ifade eder. Bir diğer tanımlamayla dijital bankacılık, elektronik araçlar kullanılarak yapılan, genellikle bireysel ve/veya küçük değerli bankacılık işlemlerinin genel adıdır (Kurnia, Peng ve Liu, 2010).

Dijital bankacılık, bankaların sunduğu hizmetlerin ve banka hakkındaki bilgilerin, mekân ve zaman sınırlaması olmaksızın bir web sayfası üzerinden müşterilere sunulmasıdır. Bir diğer deyişle, müşteriler bankanın web sayfasını ve mobil uygulamalarını kullanarak hesap bilgilerini kontrol edebilmekte, geleneksel bankacilık yönteminde yapabildikleri işlemleri web sitesi veya mobil uygulama aracılığıyla yapabilmektedir. Dijital bankacılık sistemleri, bütün bu uygulamaların banka şubesine gitmeye gerek olmaksızın yapılmasına olanak sağlamaktadır (TBB, 2012).

Dijitalleşen dünyada yaşanan gelişmeler bankacılık sektörünü de etkilemiş ve Türkiye'de bankacılık, bilgi ve iletişim teknolojilerinin en fazla kullanıldığ1 sektörlerden biri haline gelmiştir. Geçmişte, dijital bankacılık kavramı ilk olarak bankalardaki otomasyon sistemlerini ve bankalar arası EFT sistemini akla getirmekteydi. Elektronik bankacılık faaliyetleri günümüzde dijital bankacılığın değişen tanımına paralel olarak; ATM, Telefon Bankacılığ 1 , İnternet Bankacılığı, Mobil Bankacılık ve SWIFT olarak tanımlanmaktadır.

Türkiye'de ilk ATM, "Bankamatik" adıyla 1987 yılında Türkiye İş Bankası tarafından kullanılmaya başlanmıştır. Sonraki yıllarda ATM'lerde kartsız işlem uygulaması ve biyokimlik uygulamasıyla kimlik doğrulama işlemlerinde üst seviye güvenlik sağlayan parmak izi teknolojisini ilk kez kullanan yine aynı banka olmuştur (Türkiye İş Bankası, 2020). Satış noktası terminalleri (POS) ise ilk kez 1989 yılında kullanılmıştır. Sonrasında, Bankalararası Kart Merkezi’nin kurulması ile birlikte POS kullanımında da artış yaşanmaya başlamıştır (BKM, 2020).

1990 yılında Yapı Kredi Bankası'nın "Tele Firma” adlı ofis bankacılığ uygulaması hizmete başlamıştır. Telefon bankacılığı 1996 yılında, internet 
bankacılığı ise 1997 yılında Garanti Bankası ve İş Bankası'nın web siteleriyle hayata geçmiştir (Onay ve Helvacioğlu, 2007).

Türkiye'de ilk dijital bankacıllk uygulaması, Finansbank tarafindan 2012 yılında "enpara.com" adıyla gerçekleşmiştir. Enpara.com, tüm işlemlerini sadece internet üzerinden yürüten Türkiye'nin ilk dijital bankasıdır (QNB Finansbank, 2020). 2000'li yıllarda internet teknolojisinin yaygınlaşmasıyla birlikte müşteriler ile işletmeler arasındaki alışverişin internet üzerinden yapılabilmesini sağlayan sanal POS uygulamasinı ilk kez devreye alan Garanti Bankası, ilerleyen dönemlerde internet üzerinden alışverişlerin artacağını öngörerek sanal kredi kartı uygulamasını da başlatmıştır (Garanti Ödeme Sistemleri, 2020).

2006 yılında yürürlüğe giren Bilgi Toplumu Stratejisi Eylem Planı ebankacılık uygulamalarını öncelikli alan olarak belirlemiştir (DPT, 2006). E-devlet uygulaması kapsamında bankaların elektronik ortamda kamu tahsilatlarını gerçekleştirebilmesi, bireysel müşterilere verilen hizmetlerin çeşitlilik kazanması ile elektronik bankacılığın müş̧teriler tarafından kullanımı artmaya başlamıştır (Yurttadur ve Süzen, 2016).

Türkiye'de bankacılık sektöründe şubeleşme çabaları 2014 yılında zirveyi görmüş, sonrasında dijitalleşmeyle birlikte şube sayıları azalmaya başlamıştır (TBB, 2020). Aynı etki personel sayıları üzerinde de hissedilmiş ve Şekil 1'de gösterildiği üzere sektörde çalışan personel sayısı 2015 yılında 201.481 iken 2019 yılına gelindiğinde 190.908'e düşmüştür.

Şekil 1. Türkiye bankacılık sektöründe personel sayısı (TBB, 2020)

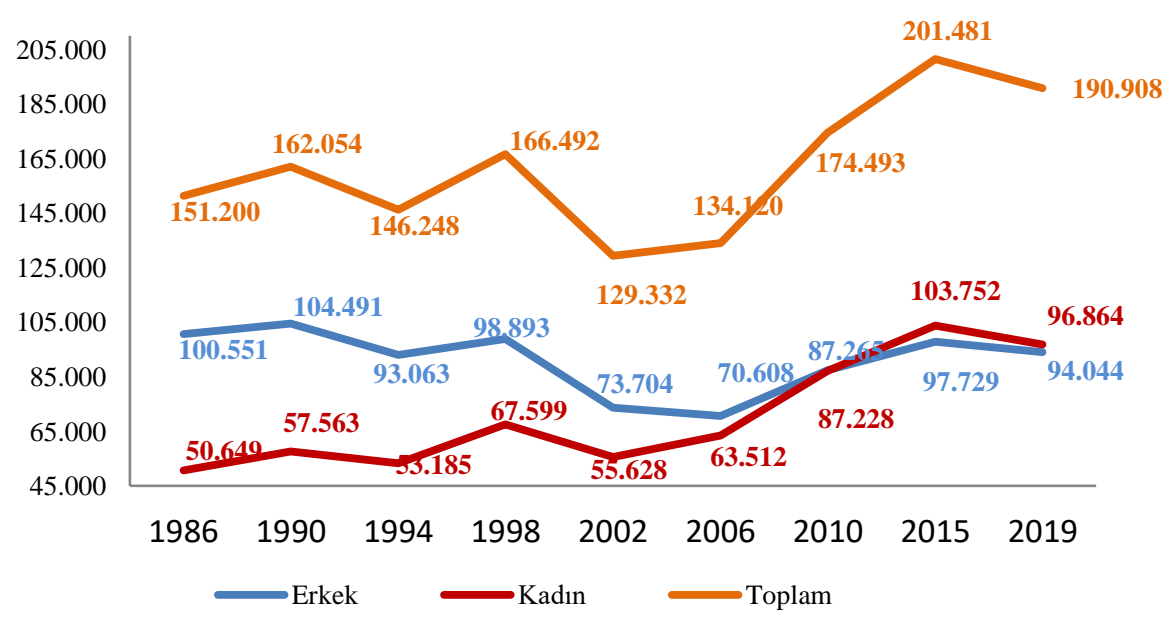

Tablo 1'de görüldüğü gibi Türkiye'de internet bankacılığının kullanım oranı son 14 y1lda önemli bir artış göstermiştir (TBB, 2020). 2015 yılından 2019 yılına gelindiğinde ise bu sayının düsserek 11.984.716'ya gerilediği görülmektedir. Bunun en önemli nedeni telefon teknolojilerinin gelişimiyle mobil bankacıllı̆ı̆n, internet bankacılığının önüne geçmesidir. 
Tablo 1. Türkiye'de İnternet Bankacılığı Müşteri Sayıları

\begin{tabular}{ccccccc}
\hline & \multicolumn{2}{c}{ Bireysel } & \multicolumn{2}{c}{ Kurumsal } & \multicolumn{2}{c}{ Toplam } \\
\hline \multirow{2}{*}{ Dönem } & $\begin{array}{c}\text { Kayıtlı } \\
\text { Müşteri }\end{array}$ & Aktif Müşteri & $\begin{array}{c}\text { Kayıtlı } \\
\text { Müşteri }\end{array}$ & $\begin{array}{c}\text { Aktif } \\
\text { Müşteri }\end{array}$ & $\begin{array}{c}\text { Kayıtlı } \\
\text { Müşteri }\end{array}$ & Aktif Müşteri \\
\hline 2006 & - & 2.976 .292 & - & 391.565 & - & 3.367 .857 \\
2010 & 7.974 .788 & 6.038 .342 & 813.721 & 655.490 & 8.788 .509 & 6.693 .832 \\
2015 & 23.899 .879 & 16.169 .883 & 1.547 .822 & 1.250 .568 & 25.447 .701 & 17.420 .451 \\
2019 & 21.518 .340 & 10.713 .960 & 1.784 .343 & 1.270 .756 & 23.302 .683 & 11.984 .716 \\
\hline
\end{tabular}

Kaynak: TBB (2020)

Dikkat çeken bir diğer unsur da 2015-2019 yılları arasında internet bankacılığı kullanımında yaşanan bu düşüşün tamamına yakınının bireysel bankacılık işlemlerinde gerçekleşmiş olmasıdır. Kurumsal müşterilerin internet bankacılığını kullanmaya devam ettiği ancak bireysel müşterilerin internet bankacıllğını terk ederek Tablo 2'de görüldüğü gibi mobil bankacılığa yöneldiği gözlemlenmektedir. Önceleri sınırlı sayıda işleme aracılık eden mobil uygulamaların gelişmesi ve sunduklarının web bankacılı̆̆ına yaklaşması neticesinde bu eğilimin devam edeceği düşünülmektedir.

Tablo 2. Türkiye Mobil Bankacılık Müşteri Sayıları

\begin{tabular}{cccccccc}
\hline & \multicolumn{2}{c}{ Bireysel } & \multicolumn{2}{c}{ Kurumsal } & \multicolumn{2}{c}{ Toplam } \\
\hline \multicolumn{2}{c}{ Dönem } & $\begin{array}{c}\text { Kayıtlı } \\
\text { Müşteri }\end{array}$ & $\begin{array}{c}\text { Aktif } \\
\text { Müşteri }\end{array}$ & $\begin{array}{c}\text { Kayıtlı } \\
\text { Müşteri }\end{array}$ & $\begin{array}{c}\text { Aktif } \\
\text { Müşteri }\end{array}$ & $\begin{array}{c}\text { Kayıtlı } \\
\text { Müşteri }\end{array}$ & $\begin{array}{c}\text { Aktif } \\
\text { Müşteri }\end{array}$ \\
\hline 2011 & - & - & - & - & 642.649 & 445.723 \\
2013 & - & - & - & - & 12.462 .702 & 9.403 .096 \\
2015 & 15.001 .699 & 11.778 .445 & 529.650 & 385.923 & 15.531 .349 & 12.164 .368 \\
2019 & 57.272 .437 & 47.799 .256 & 1.907 .248 & 1.479 .308 & 59.179 .685 & 49.278 .564 \\
\hline
\end{tabular}

Kaynak: TBB (2020)

Tablo 3'te sunulan 2020 yılı verilerine göre müşterilerin dijital bankacılık uygulamalarından mobil bankacıllğı oldukça benimsedikleri gözlenmektedir. Buna göre; yalnızca mobil bankacılık kullanan müşteri sayısı sadece internet bankacılığ1 kullanan müşteri sayısının 11 katına ulaşmıştır.

Tablo 3. Türkiye Dijital Bankacılık Aktif Müşteri Sayıları

\begin{tabular}{lcccc}
\hline \multicolumn{5}{c}{ Aktif Müsteri Sayısı } \\
\hline $\begin{array}{c}\text { Sadece İnternet } \\
\text { Bankacıllığ Kullanan }\end{array}$ & $\begin{array}{c}\text { Sadece Mobil } \\
\text { Bankacilı Kullanan }\end{array}$ & $\begin{array}{c}\text { Hem İnternet Hem Mobil } \\
\text { Bankacilık Kullanan }\end{array}$ & \multirow{2}{*}{ Toplam } \\
\hline Mart 2020 & 3.843 .206 & 44.068 .436 & 8.412 .768 & 56.324 .410 \\
\hline Kaynak: TBB (2020) & & &
\end{tabular}

Kaynak: TBB (2020)

\section{B. Müşteri Deneyimi}

İnsanlar, bir durumla karşılaştıklarında önceki deneyimlerine dayalı davranışlar sergilerler (Diresehan, 2012). Müşteri deneyimi ise bir ürün ile firma arasındaki, duyusal, rasyonel, duygusal, fiziksel ve ruhsal etkileşimleri ve bu etkileşimler ile yaratılan deneyimi kapsamaktadır (Subaş1, 2018). Müşteri deneyimi, çevresel faktörlerin birleşiminden müşteri tarafından satın alınan ürün ve hizmetlerin toplam çıktısı olarak da tanımlanabilir (Walls vd., 2011). Bu konuda istenen müşteri deneyimini teşvik etmek için pazarlamacılar, doğru ayarlamaları ve çevresel koşulları yerine getirmelidir.

Tüketim hareketinin deneyimsel yönleri olduğunu öne sürerek satın almayı gerçek bir deneyim olarak tanımlayan Holbrook ve Hirschman (1982), çalışmalarında şirketlerin tüketici araştırmalarının öneminin farkında olmalarını, davranışsal değişiklikleri kabul etmelerini ve deneysel bir yaklaşıma yönelmelerini 
vurgular. Tüketici, arzularını tatmin etmeye çalışan, sürekli deneyim arayışı içinde olan bir varlık olarak kabul edilir ise bu arzuların sürekli gelişeceği düşünülebilir. Dolayısıyla, deneyimin tüketici kültüründe kilit bir rol üstlendiği anlaşılabilir.

Deneyim sağlayabilmek için var olması gereken bazı özellikler bulunmaktadır. Tüketici deneyimi tasarlamanın Shaw ve Ivens (2002) tarafindan öne sürülen yedi unsuru aşağıda belirtilmiştir.

a. İşletmeler, rekabet avantajı elde ederek ayakta kalabilmek için belirli bir kaynak oluşturmalıdır.

b. İyi müşteri deneyimi, tüketicilerin duygusal ve fiziksel beklentilerine doğru cevapları vermekle sağlanır.

c. Müşteri deneyimi tasarlanırken planlanmış duyguların harekete geçirilmesine odaklanılmalıdır.

d. İyi bir müşteri deneyimi için müşteriler işletmenin hep odak noktası olmalıdır ve müşteri beklentileri göz önünde bulundurulmalıdır.

e. İyi bir müşteri deneyimi için müşterilerin ürün veya hizmet hakkındaki geri bildirimleri alınmalıdır.

f. İyi bir müşteri deneyimi, maliyet ve giderleri azaltarak işletmeye kâr artış1 sağlamalıdır.

g. İyi bir müşteri deneyimi oluşturmanın yolu müşteriler için her yerde özel deneyimler sunulmasından geçmektedir.

Dijital müşteri deneyimi, teknolojik gelişmelerin gelişimi ve çevrimiçi ortamın artan önemi nedeniyle giderek daha önemli hale gelmiştir. Müşteriler, 7/24 erişilebilirlik ile çevrimiçi platformlarda zaman ve esneklik dâhil birçok avantajdan yararlanmaktadır (Oral, 2019).

Dijital mağazaların müşteri deneyimindeki özel bir avantajı, müşterilerin kendi evlerinin konforunda alışveriş yapabilmeleridir. Çevrimiçi mağazaların özel avantajlarından biri de geniş ürün yelpazesidir. Kullanıcının olumlu deneyimleri çevrimiçi satışlar için önemli bir rol oynar, çünkü bir satıcıdan diğerine geçme maliyeti büyük ölçüde azalmaktadır. Fiziksel mağazalar arasında hareket etmek zaman alıcıdır ve daha uzun veya daha sık yolculuklar içerebilirken, arama motorları tüketicilerin mağazalar arasında hareket etmesini kolaylaştırır. $\mathrm{Bu}$ gelişmeleri bankacılık perspektifinden inceleyen Aktaş (2019), müşterilerin tercih ettikleri iletişim kanalları da dâhil olmak üzere, bankacılık alanında müşteri deneyimine ilişkin bazı istatistikleri şu şekilde özetlemiştir:

a. Milenyum kuşağının \%50'si daha iyi mobil veya dijital yetenekler sunan bankalara geçiş yapabileceklerini belirtmektedirler. Bununla birlikte; dijital hizmet uygulamalarından yararlanan tüketiciler, canlı müşteri temsilcilerinin sunduğu kişiselleştirilmiş hizmetleri özlediklerini belirtmektedirler.

b. Tüketicilerin \%90'1, müşteri hizmetleri konusunda bir soru sorduklarında aldıkları ilk cevabı "önemli" veya "çok önemli" olarak değerlendirmektedir. 
c. Tüketicilerin \%33'ü, müşteri hizmetlerinden yardım alırken en rahatsız edici buldukları konunun, bekletilmek ve/veya söylenenleri tekrar etmek zorunda kalmak olarak belirtmektedirler.

d. 2023 yılında müşterilerin self servis etkileşimlerini başlatmak için \%70 oranında konuşma arabirimlerini kullanmayı tercih edecekleri düşünülmektedir. $\mathrm{Bu}$ oran günümüzde $\% 40$ civarındadır.

\section{Müşteri Sadakati, Müşsteri Tatmini ve Tavsiye Eğilimi}

Müşteri sadakatinin alanyazında pek çok tanımı yapılmıştır. Oyman (2002) müşteri sadakatini, "bir markaya veya işletmeye duyulan bağl1lı" olarak tanımlamıştır. Altıntaş'a (2000) göre müşteri sadakati, daha önceden bilinen ya da tavsiye edilmiş olan bir malı gelecekte yeniden satın alma eğilimine yoğun şekilde yönelme ve katılmadır. Baytekin (2005), müşteri sadakatini, "müşterilerin tüm rekabetçi etkilere ne ölçüde direndiği ve işletmenin ürün ve hizmetlerini kullanmakta ne kadar kararlılık gösterdiği”" şeklinde tanımlamıştır.

Duffy (1998) farklı bir tanımlama getirerek, müşteri sadakatini, işletmenin müşteriler ile kuvvetli ve derin ilişkiler yaratması olarak tanımlamıştır. Sadık müşteriler, ürün veya hizmet aldıkları işletmeden istedikleri zaman tekrar alım yapıyor ve bu ürünleri çevrelerine tavsiye ediyorlarsa ve dahası bu işletmeye karşı olumlu tutumlar sergilemeyi sürdürüyorlarsa müssteri sadakatinden bahsedilmektedir (Kandampully ve Suhartanto, 2000). Müşteri sadakati yönetimi konusunda başarılı olan bir işletme, tıpkı bir mıknatıs gibi müşterilerini kendisine çekebilmektedir (Bell ve Bell, 2004).

Günümüzde pazarlama hedefleri, işletmeler açısından pazarda rakiplerinin önüne geçebilmek adına büyük önem taşımaktadır. En önemli pazarlama hedeflerinden biri de müşteri sadakatidir. Müşteri sadakatini arttırmak için sarf edilen çabanın işletme maliyetlerini arttıracağı düşünülse de çoğu zaman tersi gerçekleşir. $\mathrm{Bu}$ türden sadık müşterilerin sayısı arttıkça, işletmelerin fiyat politikalarında esneklik kabiliyetleri de artmaktadır. Sadakati yüksek olan müşteriler, bir yandan da reklam aracı olarak işletmeye yeni müşteriler kazandırmaktadır. Müşterilerin beklentileri tatmin düzeylerini oluştururken, aynı işletmeyi seçmelerinin sürdürülebilir olması ise bağlılıklarını göstermektedir. Bütün sadık müşterilerin tatmin düzeylerinin yüksek olduğu, bunun yanında her tatmin olan müşterinin sadakatinin yüksek olmayabileceği belirtilmektedir (Arı ve Yılmaz, 2015). Hizmet kalitesini üst düzeyde tutarak müşteri tatminini sağlayabilmek işletmeler için kilit bir nokta oluşturmaktadır çünkü sadakati oluşturan temel unsurlardan biri de müşteri tatminidir. Tatmin edilmiş müşterinin işletmeye bağlılığı artacak ve işletmenin imajının yükselmesine yardımcı olacaktır. Böylece işletme, rakiplerine oranla avantaj sağlayacak ve pazardaki yerini koruyacaktır (Tan vd., 2016).

Müşteri tatmini kavramı ile tüketicilerin ürün ve hizmetlerden elde ettiği hoşnutluk ifade edilmektedir. Oliver'e göre (1997) tatmin, "ürün ve hizmetin özelliği veya ürün ve hizmetin kendisi ile ilgili müşterinin memnun olmasına olanak sağlamaktadır". Müşteri tatmini ise arzu, ihtiyaç ve amaçları yerine getirilen tüketicilerin aldıkları hizmetten memnuniyetini ifade etmektedir. Del Bosque ve 
Martin’e göre (2008) "müşteri tatmini, bilişsel olduğu kadar duygusal bir süreçtir". Oh (2000) müşteri tatminini, algılanan müşteri değerinin potansiyel bir sonucu olarak tanımlamıştır. Neal (1999) ise müşteri tatminini, tüketicilerin ürün ve/veya hizmetlerden beklentileri ile işletme performansını algılamaları arasındaki etkileşim sonucunda oluşan tutum şeklinde tanımlamıştır. Bir işletme müşterisinin taleplerine cevap veremezse müşteri, işletmeyi terk ederek rakip bir işletmeden ürün veya hizmet almaya yönelecektir. Bu nedenle bütün işletmeler, müşterilerini odak noktalarında tutarak müşteri tatminine büyük önem vermektedir.

Müşteri tatmini, müşterinin bir işletme veya marka ile oluşan deneyimini değerlendirmesi sonucu edindiği tutum olarak düşünüldüğünde, müşterinin hizmetten tatmin olması beraberinde o işletmeye ya da markaya sadakat oluşturmasını sağlamaktadır. Müşteri tatmini, müşteri sadakatini arttırarak işletmeler için daha iyi bir performans oluşturmak adına anahtar görevi görmektedir. Müşteri memnuniyeti, müşteri tatminini, müşteri tatmini, müşteri sadakatini, müşteri sadakati de müşteri tavsiye etme davranışını getirmektedir (Gronholdt, Martensen ve Kristensen, 2000).

Tavsiye etme, genel anlamıyla; müşterilerin işletme, ürün, marka veya hizmetle ilgili başka bir alıcıya aktardığı olumlu ve olumsuz öneriler olarak tanımlanabilir (Harrison-Walker, 2001). Tavsiye etme davranış1, müşteri deneyimleri sonucu ortaya çıkan olumlu davranışsal sonuçların bir göstergesi olarak düşünülür. Westbrook (1987) benzer bir tanımlama yaparak bir müşterinin diğer müşterilere belirli bir ürün veya hizmetten yararlanma veya onların özellikleri hakkında yöneltilmiş iletişim tarzı olarak tanımlamıştır. Litvin, Goldsmith ve Pan (2008) tavsiye etme davranışını, müşteriler arasında, kaynakların ticari etkilerden bağımsız olarak değerlendirildiği bir ürün, hizmet veya işletme hakkında gerçekleştirilen bir iletişim olarak tanımlamaktadır.

Bir işletmenin en önemli pazarlama araçlarından biri olarak mevcut ve potansiyel müşterilerinin etkileşim içinde bulunarak kullandıkları ürün/hizmeti, işletme ve markayı tavsiye etme davranışında bulunmaları kabul edilmektedir. Tavsiye etme davranışı, müşterilerin karar verme süreçleri üzerinde etki yaratarak davranışlarını biçimlendirmede önemli rol oynamaktadır. Özellikle bankacılık gibi hizmetler, soyut oldukları ve üretildikleri yerde tüketilmeleri gerektiği için kullanılmadan önce kontrol edilmeleri mümkün olmamaktadır. $\mathrm{Bu}$ sebeple, hizmetlerin satın alınmasında, müşterinin önceki deneyimleri ve yakın çevresinin tavsiyeleri etkili olmaktadır. Bu nedenle hizmet veren işletmeler açısından memnun kalan müşterilerin diğer müşterilere tavsiyede bulunmaları, işletmenin karlılı̆̆ üzerinde olumlu etkilerde bulunmaktadır (Choudhury, 2013).

\section{YÖNTEM}

\section{A. Araştırma Modeli}

Araştırmanın bağımsız değişkeni olan müşteri deneyiminin alanyazında altı alt boyut ile işlendiği gözlenmektedir. Bunlar; kullanışlılık, kullanım kolaylığ 1 , bilgi içeriği, işlem hızı, güvenlik, müşteri desteğidir. Dijital bankacılık ile şekillenen müşteri deneyiminin müşteri sadakati, memnuniyeti $\mathrm{v}_{\mathrm{v}} \mathrm{H}_{3}$ üşterilerin tavsiye eğilimindeki etkilerini ele alan araşt $\mathrm{H}_{1 \ldots i}$ a modeli Şekil 2 'de belirtilmiştir. 


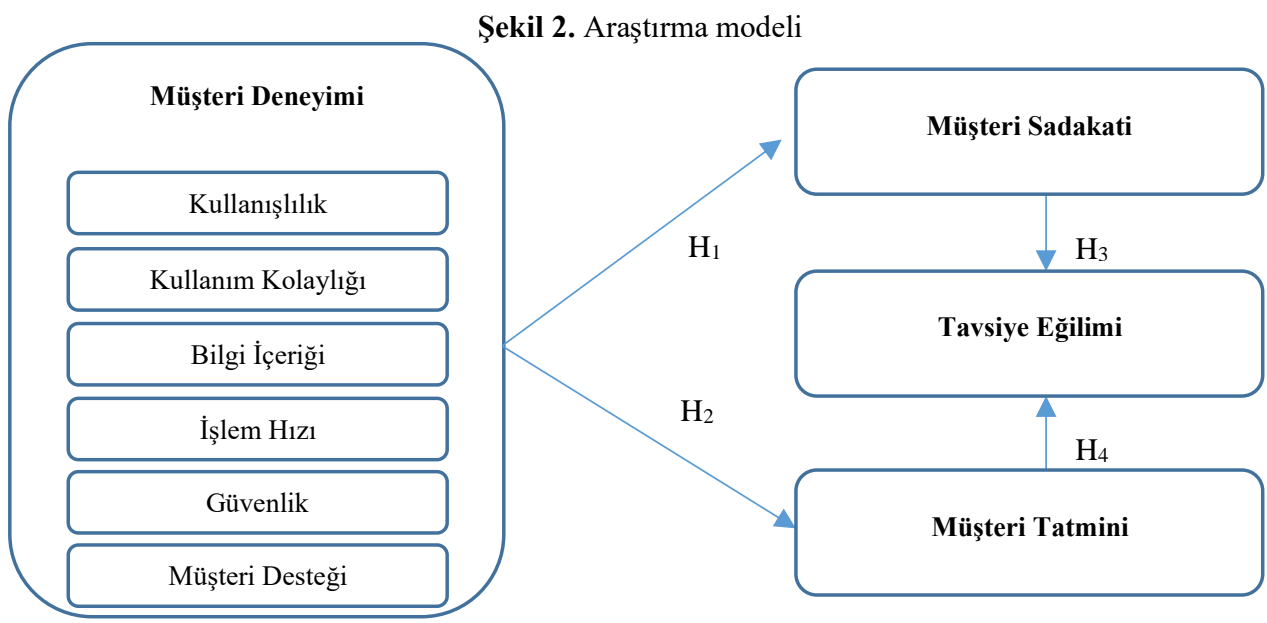

Araştırmada ele alınan değişkenlerin birbiri arasındaki ilişkileri incelemek için geliştirilen araştırma hipotezleri şu şekildedir:

$\mathbf{H}_{1 \mathbf{x}}$ : Dijital bankacılık uygulamalarında müşteri deneyimi [(a) kullanışlılık, (b) kullanım kolaylığı, (c) bilgi içeriği, (d) işlem hızı, (e) güvenlik, (f) müşteri desteği], müssteri sadakati üzerine etki yapmaktadır.

$\mathbf{H}_{2 \mathbf{x}}$ : Dijital bankacılık uygulamalarında müşteri deneyimi [(a) kullanışl11ık, (b) kullanım kolaylığı, (c) bilgi içeriği, (d) işlem hızı, (e) güvenlik, (f) müşteri desteği], müşteri tatmini üzerine etki yapmaktadır.

$\mathbf{H}_{3}$ : Dijital bankacılıkta müşteri sadakati, müşterilerin tavsiye eğilimini etkiler.

$\mathbf{H}_{4}$ : Dijital bankacılıkta müşteri tatmini, müşterilerin tavsiye eğilimini etkiler.

\section{B. Evren ve Örneklem}

Araştırmanın örneklemini Türkiye'de yaşayan ve dijital uygulamaları kullanan banka müşterilerini temsil etmek üzere kolayda örnekleme yolu ile ulaşılan 364 kişi oluşturmaktadır. Araştırma için tek bir bankanın dijital uygulaması belirlenmemiş, aksine bütün bankaların dijital uygulamalarını kullanan bireylerle çalışılmıştır.

Katılımcıların demografik özellikleri Tablo 4'te gösterilmektedir.

Tablo 4. Katılımcıların Demografik Özellikleri

\begin{tabular}{|c|c|c|c|c|c|c|c|}
\hline Değişken & Gruplar & $\mathbf{F}$ & $\%$ & Değişken & Gruplar & $\mathbf{F}$ & $\%$ \\
\hline \multirow{2}{*}{ Cinsiyet } & Kadın & 229 & 62,9 & \multirow{5}{*}{ Aylık gelir } & 2000 TL'den az & 25 & 6,9 \\
\hline & Erkek & 135 & 37,1 & & 2001-3000 TL & 63 & 17,3 \\
\hline \multirow{5}{*}{ Yaş } & $18-24$ & 50 & 13,7 & & $3001-4000 \mathrm{TL}$ & 45 & 12,4 \\
\hline & $25-31$ & 120 & 33,0 & & $4001-5000 \mathrm{TL}$ & 49 & 13,5 \\
\hline & $32-38$ & 95 & 26,1 & & 5000 TL ve üstü & 182 & 50 \\
\hline & $39-45$ & 58 & 15,9 & \multirow{3}{*}{$\begin{array}{l}\text { Dijital Banka } \\
\text { Kullanım } \\
\text { Siklığı }\end{array}$} & Ayda bir & 81 & 22,3 \\
\hline & 46 ve üstü & 41 & 11,3 & & Ayda iki & 112 & 30,8 \\
\hline \multirow{6}{*}{$\begin{array}{l}\text { Öğrenim } \\
\text { Durumu }\end{array}$} & İlkokul & 1 & 0,3 & & Her gün & 171 & 47 \\
\hline & Ortaokul & 5 & 1,4 & \multirow{6}{*}{$\begin{array}{l}\text { En Fazla } \\
\text { Kullanılan } \\
\text { Dijital } \\
\text { Bankacılık } \\
\text { Uygulaması }\end{array}$} & YKB & 83 & 22,8 \\
\hline & Lise & 34 & 9,3 & & Garanti Bankası & 76 & 20,9 \\
\hline & Yüksekokul & 69 & 19,0 & & Ziraat Bankası & 48 & 13,2 \\
\hline & Lisans & 184 & 50,5 & & İş Bankası & 41 & 11,3 \\
\hline & Lisansüstü & 71 & 19,5 & & Akbank & 30 & 8,2 \\
\hline $\begin{array}{l}\text { Medeni } \\
\text { Durum }\end{array}$ & Evli & 206 & 56,6 & & $\begin{array}{l}\text { QNB } \\
\text { Finansbank }\end{array}$ & 29 & 8,0 \\
\hline
\end{tabular}


Samet Aydın \& Ecem Onaylı / Bankacılıkta Dijital Dönüşümle Değişen Müşteri Deneyimi: Müşteri Sadakati, Memnuniyeti ve Tavsiye Eğilimine Yansımaları

\begin{tabular}{llccccc} 
& Bekâr & 158 & 43,4 & Vakıfbank & 23 & 6,3 \\
\hline \multirow{3}{*}{ Hane Halk1 } & 1 & 26 & 7,1 & Halkbank & 13 & 3,6 \\
Sayıs & 2 & 74 & 20,3 & Denizbank & 7 & 1,9 \\
& 3 & 146 & 40,1 & TEB & 5 & 1,4 \\
& 4 & 87 & 23,9 & Kuveyt Türk & 4 & 1,1 \\
& 5 ve üzeri & 31 & 8,5 & Diğer & 5 & 1,5 \\
\hline
\end{tabular}

$\mathrm{n}=364$

\section{Veri Toplama Araçları}

Araştırma değişkenlerini ölçmek için alanyazında daha önceden kullanılan, farklı araștırmalarda geçerlilik ve güvenilirliği sağlandığ 1 belirtilen ölçeklerden yararlanılmıştır. Özgün ölçeklerin Türkçe'ye tercümesi yapılmış, daha sonra bir çevirmen yardımı ile tekrar İngilizce'ye çevrilmiş elde edilen sonuçlar araştırmacılar tarafından karşılaştırılmış ve ölçüm formunun son haline ulaşı1mıştır.

\section{Müş̧teri Deneyimi Ölçeği}

Müşteri Deneyimi değişkeni için Lee (2009), Wang ve Tang (2004) ve Yoon (2010) tarafından geliştirilen ölçeklerde yer alan ifadelerden yararlanılmıştır. Müşteri Deneyimi'ni; Kullanışlılık, Kullanım Kolaylığı, Bilgi İçeriği, İşlem Hızı, Güvenlik ve Müşteri Desteği olmak üzere altı alt boyutta ele alan ölçek, toplamda 28 adet ifadeden oluşmaktadır.

\section{Müşteri Sadakati, Müşteri Tatmini ve Tavsiye Ĕ̌ilimi Ölçeği}

Şekil 3. Araştırma modeli

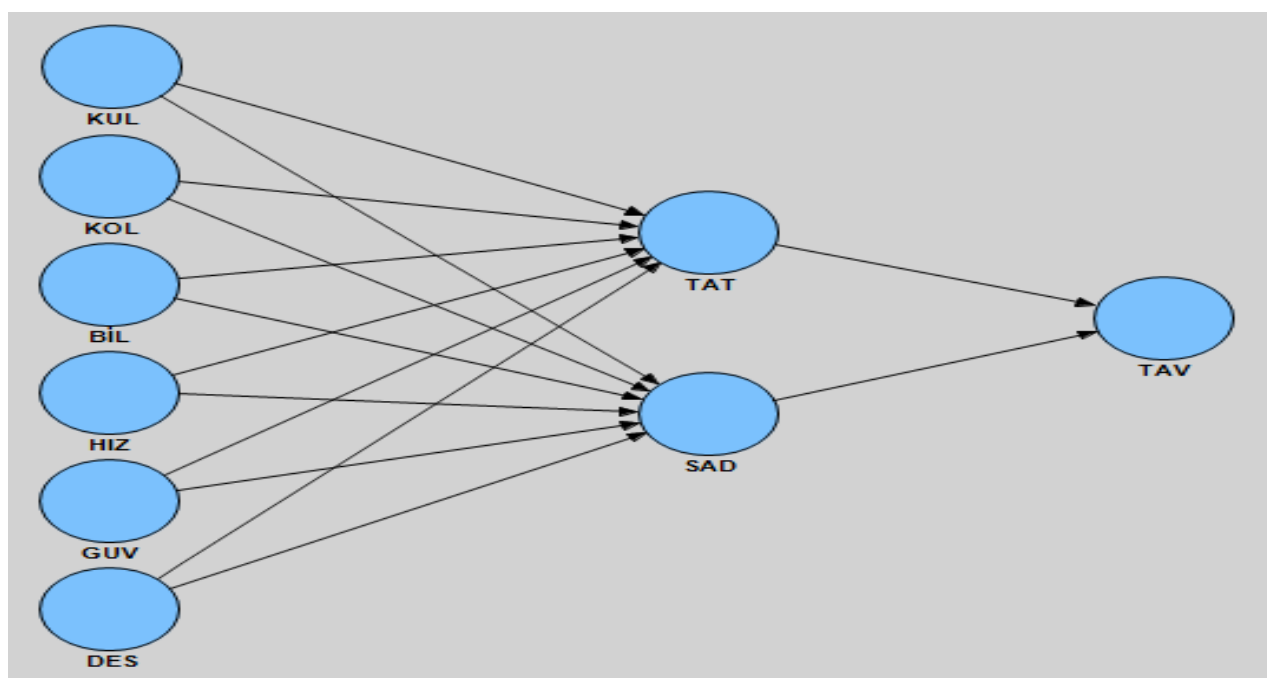

Bağımlı değişkenlerin ölçümü için Klaus ve Maclan (2013) tarafından geliştirilen ölçekler kullanılmıştır. Kavramları tek boyutlu olarak değerlendiren ölçeklerden Müşteri Sadakati Ölçeği ve Müşteri Tatmini Ölçeği beşer ifadeden, Tavsiye Eğilimi Ölçeği ise yedi adet ifadeden oluşmaktadır. Ölçeklerde yer alan ifadeler Ek 1'de gösterilmiştir.

Oluşturulan anket formunda araştırma değişkenleri beşli Likert ölçeği ile ölçülmüştür. Öncelikle bir pilot çalışma $(n=63)$ yapılmış, elde edilen verilere Keşfedici Faktör Analizi ve Güvenilirlik Analizi tetkik edilmiş, faktörlerin birbirinden ayrıldığına ve Cronbach's $\alpha$ katsayılarının 0,70 'ten büyük olduğuna 
dair sonuçların elde edilmesi üzerine veri toplanmaya devam edilmiştir. Netice itibariyle, tam olarak doldurulmuş 364 adet anket formu elde edilmiştir.

\section{Analiz}

Araştırma kapsamında toplanan verilerin analizi için Kısmi En Küçük Kareler Yapısal Eşitlik Modeli (PLS-SEM) yöntemi tercih edilmiştir (Chin, 1998). $\mathrm{Bu}$ amaçla geliştirilen programlardan Smart PLS 2 kullanılmıştır.

Doğrulayıcı faktör analizi için söz konusu yazılımda oluşturulan model Şekil 3’te gösterilmektedir. Değişkenlere ilişkin kodlamalar şu şekildedir:

- KUL: Kullanışlilık

- KOL: Kullanım Kolaylı̆̆1

- BİL: Bilgi İçeriği

- HIZ: İşlem Hızı

- GUV: Güvenlik

- DES: Müşteri Desteği

- TAT: Müşteri Tatmini

- SAD: Müşteri Sadakati

- TAV: Tavsiye Eğilimi

\section{BULGULAR}

\section{A. Ölçüm Araçlarının Geçerlilik ve Güvenilirliği}

Ölçeklerin geçerliliği ve güvenilirliği Doğrulayıcı Faktör Analizi ile test edilmiştir. Doğrulayıcı Faktör Analizinde 500 örneklemli bootstrap yöntemi ile sınama yapılmış olup sonuçta tüm ifadeler için 0,60 üzerinde faktör yükü elde edilmiştir $(t>2,57, p<0,01)$. PLS yöntemi örneklem sayısına dair bir sınırlama getirmemektedir. Buna karşın; Chin (1998) ve Hair, Ringle ve Sarstedt (2011) araştırma modelinde en fazla ifadeye sahip değişken dikkate alınarak bu değişkene ait ifade sayısının en az on katı büyüklüğünde bir örneklem olmasını tavsiye etmektedir. Bu araştırmadaki örneklem miktarının söz konusu tavsiyelere uygun olduğu görülmektedir.

Ölçek geçerliliği Doğrulayıcı Faktör Analizi ile yakınsama ve ayrışma geçerlilikleri test edilerek sınanmıştır. Buna göre; Hair ve diğerleri (2014) tarafından belirtilen (1) tüm faktörlerde ifadelerin 0.60 'dan fazla faktör yükü alması, (2) ifadelerin en büyük faktör yükünü kendi ait oldukları faktöre vermesi ve (3) faktörlerin açılanan ortalama varyansının (AVE: Average Variance Extracted) 0.50 'den büyük olması koşullarının sağlanması nedeniyle yakınsama geçerliliği (convergent validity) elde edilmiştir. Ayrışma geçerliliği (discriminant validity) ise; Doğrulayıcı Faktör Analizi sonucunda (1) çapraz yüklemeler değerlendirildiğinde ifadelerin en yüksek faktör yükünü kendi faktörlerine atamış olması (Hair vd., 2014) ve (2) Fornell ve Larcker (1981) kriterine göre her bir faktör yapısının açıklanan ortalama varyans (AVE) değerinin karekökünün, diğer yapılar ile olan korelasyonların en büyügünden nicel olarak daha büyük olması gerektiği koşullarının sağlaması üzerine elde edilmiştir. Faktör yükleri Tablo 5'te, korelasyon analizi sonuçları ve AVE değerleri Tablo 6'da gösterilmiştir. 
Samet Aydın \& Ecem Onaylı / Bankacılıkta Dijital Dönüşümle Değişen Müşteri Deneyimi: Müşteri Sadakati, Memnuniyeti ve Tavsiye Eğilimine Yansimaları

Tablo 5. Doğrulayıcı Faktör Analizi - Faktör Yükleri

\begin{tabular}{|c|c|c|c|c|c|c|c|c|c|c|}
\hline & BİL & DES & GUV & HIZ & KOL & & & SAD & TAT & TAV \\
\hline BİL1 & 0,920 & & & & & & SAD1 & 0,844 & & \\
\hline BİL2 & 0,912 & & & & & & SAD2 & 0,897 & & \\
\hline BİL3 & 0,910 & & & & & & SAD3 & 0,917 & & \\
\hline BİL4 & 0,921 & & & & & & SAD4 & 0,805 & & \\
\hline DES1 & & 0,877 & & & & & SAD5 & 0,825 & & \\
\hline DES2 & & 0,916 & & & & & TAT1 & & 0,869 & \\
\hline DES3 & & 0,915 & & & & & TAT2 & & 0,853 & \\
\hline GUV1 & & & 0,844 & & & & TAT3 & & 0,899 & \\
\hline GUV2 & & & 0,890 & & & & TAT4 & & 0,898 & \\
\hline GUV3 & & & 0,772 & & & & TAT5 & & 0,897 & \\
\hline GUV4 & & & 0,685 & & & & TAV1 & & & 0,809 \\
\hline GUV5 & & & 0,873 & & & & TAV2 & & & 0,832 \\
\hline GUV6 & & & 0,870 & & & & TAV3 & & & 0,900 \\
\hline HIZ1 & & & & 0,922 & & & TAV4 & & & 0,917 \\
\hline HIZ2 & & & & 0,942 & & & TAV5 & & & 0,924 \\
\hline HIZ3 & & & & 0,910 & & & TAV6 & & & 0,925 \\
\hline HIZ4 & & & & 0,891 & & & TAV7 & & & 0,928 \\
\hline KOL1 & & & & & 0,799 & & TAV3 & & & 0,900 \\
\hline KOL2 & & & & & 0,889 & & TAV4 & & & 0,917 \\
\hline KOL3 & & & & & 0,898 & & TAV5 & & & 0,924 \\
\hline KOL4 & & & & & 0,899 & & TAV6 & & & 0,925 \\
\hline KOL5 & & & & & 0,904 & & TAV7 & & & 0,928 \\
\hline KOL6 & & & & & 0,879 & & & & & \\
\hline KUL1 & & & & & & 0,891 & & & & \\
\hline KUL2 & & & & & & 0,819 & & & & \\
\hline KUL3 & & & & & & 0,786 & & & & \\
\hline KUL4 & & & & & & 0,770 & & & & \\
\hline KUL5 & & & & & & 0,906 & & & & \\
\hline
\end{tabular}

KUL: Kullanışlılık, KOL: Kullanım Kolaylığı, BİL: Bilgi İçeriği, HIZ: İşlem Hızı, GUV: Güvenlik, DES: Müşteri Desteği, TAT: Müşteri Tatmini, SAD: Müssteri Sadakati, TAV: Tavsiye Eğilimi

Tablo 6. Korelasyon Analizi

\begin{tabular}{|c|c|c|c|c|c|c|c|c|c|c|c|c|}
\hline & & AVE & $\sqrt{ } \mathrm{AVE}$ & 1 & 2 & 3 & 4 & 5 & 6 & 7 & 8 & 9 \\
\hline 1 & Bilgi İçeriği & 0,839 & 0,916 & 1,000 & & & & & & & & \\
\hline 2 & Müşteri Desteği & 0,815 & 0,903 & 0,837 & 1,000 & & & & & & & \\
\hline 3 & Güvenlik & 0,681 & 0,825 & 0,698 & 0,713 & 1,000 & & & & & & \\
\hline 4 & İşlem Hızı & 0,840 & 0,916 & 0,827 & 0,764 & 0,693 & 1,000 & & & & & \\
\hline 5 & Kullanım Kolaylığg & 0,772 & 0,878 & 0,778 & 0,754 & 0,637 & 0,793 & 1,000 & & & & \\
\hline 6 & Kullanışlılık & 0,699 & 0,836 & 0,786 & 0,753 & 0,673 & 0,801 & 0,811 & 1,000 & & & \\
\hline 7 & Müşteri Sadakati & 0,752 & 0,867 & 0,650 & 0,643 & 0,562 & 0,676 & 0,741 & 0,693 & 1,000 & & \\
\hline 8 & Müşteri Tatmini & 0,781 & 0,884 & 0,720 & 0,730 & 0,637 & 0,705 & 0,775 & 0,778 & 0,818 & 1,000 & \\
\hline 9 & Tavsiye Eğilimi & 0,795 & 0,892 & 0,720 & 0,744 & 0,634 & 0,715 & 0,757 & 0,743 & 0,759 & 0,796 & 1,000 \\
\hline
\end{tabular}

Ölçek güvenilirliği ise kompozit güvenilirlik (Composite reliability) ve Cronbach's $\alpha$ değerlerinin tüm faktörler için 0,70 'ten büyük olması ile elde edilmiştir. Sonuçlar Tablo 7'de sunulmuştur.

Tablo 7. Güvenilirlik Analizi

\begin{tabular}{lcr}
\hline Değisskenler & Composite Reliability & Cronbach's $\alpha$ \\
\hline Bilg̨ İçeriği & 0,954 & 0,936 \\
Müşteri Desteği & 0,930 & 0,887 \\
Güvenlik & 0,927 & 0,905 \\
İşlem Hızı & 0,954 & 0,936 \\
Kullanım Kolaylı̆̆ı & 0,953 & 0,940 \\
Kullanışlllık & 0,920 & 0,891 \\
Müşteri Sadakati & 0,924 & 0,889 \\
Müşteri Tatmini & 0,947 & 0,930 \\
Tavsiye Eğilimi & 0,965 & 0,957 \\
\hline
\end{tabular}




\section{B. Hipotezlerin Test Edilmesi}

Araştırma hipotezlerinin test edilmesi için PLS-SEM analizleri gerçekleştirilmiştir. " $\mathrm{H}_{1 \mathrm{x}}$ : Dijital bankacılık uygulamalarında müşteri deneyimi, müşteri sadakati üzerine etki yapmaktadır." hipotezi için yapılan değerlendirmede Müşteri Sadakati üzerinde Kullanım Kolaylı̆̆ $(\beta=0,436$; $p<0,01)$ ve Kullanışlık'ın $(\beta=0,168 ; p<0,01)$ anlamlı etkisi saptanmış olup Bilgi İçeriği $(\beta=-0,015 ; p>0,01)$, Müşteri Desteği $(\beta=0,079 ; p>0,01)$, Güvenlik $(\beta=0,043 ; p>0,01)$, İşlem Hızı'nın $(\beta=0,118 ; p>0,01)$ anlamlı etkisi gözlenmemiştir $\left(\mathrm{R}^{2}=0,584\right)$. Bu sonuçlar üzerine $\mathrm{H}_{1 \mathrm{~A}}$ ve $\mathrm{H}_{1 \mathrm{~B}}$ desteklenmiş; $\mathrm{H}_{1 \mathrm{C}}, \mathrm{H}_{1 \mathrm{D}}, \mathrm{H}_{1 \mathrm{E}}$ ve $\mathrm{H}_{1 \mathrm{~F}}$ ise reddedilmiştir.

"H $\mathrm{H}_{2 \mathrm{x}}$ : Dijital bankacılık uygulamalarında müşteri deneyimi, müşteri tatmini üzerine etki yapmaktadır." hipotezi için yapılan değerlendirmede Müşteri Tatmini üzerinde Kullanım Kolaylığ $(\beta=0,325 ; \mathrm{p}<0,01)$ ve Kullanışlık'ın $(\beta=0,327 ; p<0,01)$ anlamlı etkisi saptanmış olup Bilgi İçeriği $(\beta=0,031 ; p>0,01)$, Müşteri Desteği $(\beta=0,179 ; p>0,01)$, Güvenlik $(\beta=0,086 ; p>0,01)$, İşlem Hızı'nın $(\beta=-0,036 ; p>0,01)$ anlamlı etkisi gözlenmemiştir $\left(R^{2}=0,688\right)$. Bu sonuçlar üzerine $\mathrm{H}_{2 \mathrm{~A}}$ ve $\mathrm{H}_{2 \mathrm{~B}}$ desteklenmiş; $\mathrm{H}_{2 \mathrm{C}}, \mathrm{H}_{2 \mathrm{D}}, \mathrm{H}_{2 \mathrm{E}}$ ve $\mathrm{H}_{2 \mathrm{~F}}$ ise reddedilmiştir.

" $\mathrm{H}_{3}$ : Dijital bankacılıkta müşteri sadakati, müşterilerin tavsiye eğilimini etkiler." hipotezi için yapılan değerlendirmede Tavsiye Eğilimi üzerinde Müşteri Sadakati'nin anlamlı etkisi saptanmış $(\beta=0,325 ; \mathrm{p}<0,01)$ ve hipotez desteklenmiştir. " $\mathrm{H}_{4}$ : Dijital bankacılıkta müşteri tatmini, müşterilerin tavsiye eğilimini etkiler." hipotezi için yapılan değerlendirmede Tavsiye Eğilimi üzerinde Müşteri Tatmini'nde de benzer şekilde anlamlı etkisi saptanmış $(\beta=0,529 ; \mathrm{p}<0,01$ ve hipotez desteklenmiştir $\left(\mathrm{R}^{2}=0,668\right)$.

Analiz sonuçları Tablo 8'de sunulmuştur. Regresyon katsayılarının anlamlılık düzeyi bootstrap işlemi ile belirlenmiştir.

Tablo 8. PLS Analizi ile Hipotez Testleri

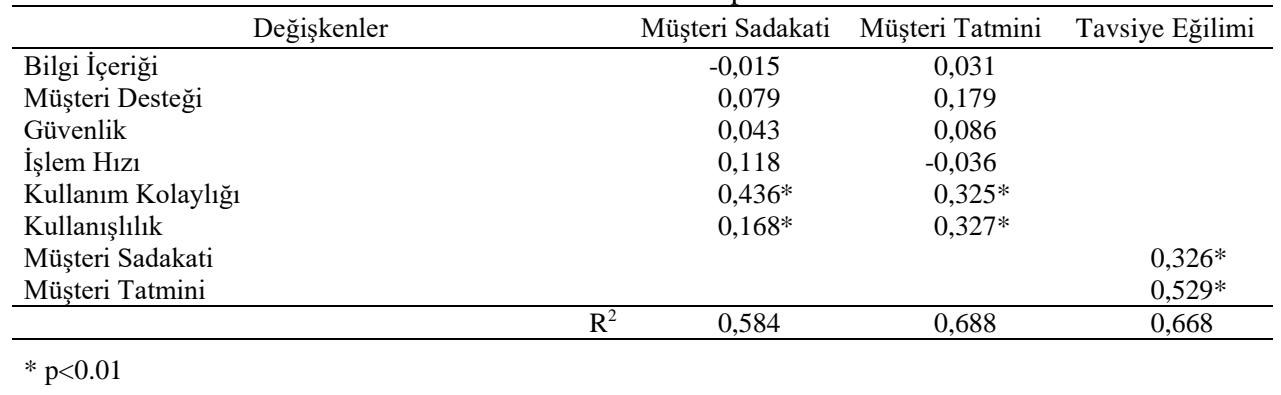

\section{TARTIŞMA VE SONUÇ}

Günümüzdeki rekabet ortamında olumlu bir müşteri deneyimi yaratmanın amacı, rakiplerden farklılaşarak öne çıkma arzusuyla ilgilidir. Bankalar da diğer tüm işletmeler gibi rekabette öne geçebilmek için farklılaşma çabasına girmişlerdir. Bankacılık sektörünün son yıllarına bakıldığında teknolojik gelişmelerin yansıması çok net bir şekilde görülmektedir, internet ve iletişim teknolojilerinde yaşanan hızlı gelişmeler bankalar için dijital dönemi başlatmış ve dijital bankacılık uygulamaları hayata geçirilmiştir. 
$\mathrm{Bu}$ çalışma; dijital bankacılık uygulamaları sırasında yaşanan müşteri deneyiminin, müşteri sadakati, müşteri tatmini ve tavsiye eğilimi üzerindeki etkilerini incelemek amacıyla yapılmıştır. Araştırmada müşteri deneyiminin müşteri sadakatine ve müşteri tatminine etkisi incelendiğinde, müşteri deneyiminin alt boyutlarından kullanım kolaylığı ve kullanışlılığın gerek müşteri sadakati gerekse müşteri tatmini üzerinde pozitif bir ilişkisi olduğu saptanmıştır. Söz konusu durum müşteri deneyiminin diğer alt boyutları için gözlenmemiştir.

Alanyazında, müşteri deneyiminin müşteri sadakati, müşteri tatmini ve tavsiye eğilimi üzerinde pozitif yönlü bir etkisi olduğunu gösteren araştırmalar bulunmaktadır. Örneğin, çevrimiçi bankacılık uygulamalarını kullanma sıklığına göre iki gruba ayırarak analiz eden Yoon (2010), yüksek deneyim grubunda müşteri tatmini konusunda kullanım kolaylığı ve müşteri destek hizmetinin, düşük deneyim grubunda müşteri tatmini için kullanım kolaylığı, tasarım ve işlem hızının etkili olduğunu tespit etmiştir. Tang ve diğerleri (2010), mobil bankacılıkta müşteri deneyimi üzerine yaptıkları araştırmada kullanım kolaylığı, kullanışlılık ve güvenilirliği, tavsiye niyetinin önemli öncülleri olarak belirtmiştir.

$\mathrm{Bu}$ araştırmanın sonuçları bahsi geçen çalışmalarla belirli ölçülerde örtüşmekte bazı açılardan ise ayrışmaktadır. Müşteri deneyimine ilişkin olarak araştırma sonuçları değerlendirildiğinde müşterilerin dijital bankacılık uygulamaları arasında hız, müşteri desteği, güvenlik ve bilgi içeriği boyutlarında belirgin bir fark algılamadıkları anlaşılmaktadır. Bu sonuç güvenlik boyutu için değerlendirilirken Bankacılık Düzenleme ve Denetleme Kurumunun sektördeki temel ölçütleri belirlediği ve tüm bankaların bunlara uymasını beklediği göz önüne alınmalıdır. $\mathrm{Bu}$ nedenle müşteriler güvenlik açısından bankaları farklı görmemektedir. Benzer sonuç aynı teknolojiyi kullanan bankaların müşterilerine sundukları hız konusunda da birbirinden ayrışmıyor olmalarıdır. Özellikle mobil cihazlarda sıklıkla yapılan güncellemelerle uygulamalar her daim geliştirilmekte olup müşteriler tarafından saptanan aksaklıklar hızlıca düzeltilmektedir. Müssteri desteği ve bilgi içeriği kısmında da müşterilerine hemen hemen aynı ürünleri sunan bankaların birbirine yakın hizmet verdiği anlaşılmaktadır.

Araştırmada dikkat çeken sonuç sunulan dijital uygulamaların müşteriler tarafından kullanım kolaylığı ve kullanışlılığına yapılan vurgudur. Zira yapılan işlemlerde müşteri tatmini ve müşterinin bankaya sadakati bu iki özellik tarafından belirlenmektedir. Dolayısıyla, bankaların dijital uygulamalarındaki menüleri kullanıcı dostu bir şekilde tasarlamaları, aranan işlemin hızlı bir şekilde bulunmasını sağlamaları önemlidir. Birçok banka tarafindan son zamanlarda tanıtılan sanal asistanlar da bu amaca hizmet etmektedir. İşlem hızı, güvenliği ve bilgi içeriğinde standartlaşmanın olması sektörün çalışma biçiminde söz sahibi kurum ve kuruluşların çabası, buna ilaveten kanun ve yönetmeliklerin getirdiği çerçeve nedeniyle olağan karşılanabilir. Araştırma sonuçları bu gelişmeler ile uyumludur.

Araştırmada incelenen hipotezlerden bir diğeri "müşseri sadakati tavsiye eğilimini etkiler" şeklindedir. Çalışmada alanyazın ile aynı yönde müspet sonuç elde edilmiştir (Gronholdt vd., 2000; Kandampully ve Suhartanto, 2000). Benzer 
şekilde "müşseri tatmini tavsiye eğilimini etkiler" hipotezi desteklenmiş olup bu sonuçlar daha önce Rust ve Zahorik (1993) ve Lee ve diğerlerinin (2007) bulguları ile aynı doğrultudadır.

$\mathrm{Bu}$ araştırmanın en önemli sınırlılığını örneklem hacmi ve örnekleme için olasılıklı olmayan yöntemin kullanılması oluşturmaktadır. Daha geniş bir katılımcı grubu ile çalışılması gelecekteki araştırmalar için önerilmektedir. Ayrıca, kişisel verilerin ve ticari sırların korunması kaydıyla bir banka ile iş birliği yapılarak bankanın son zamanda kazandığı yeni müşteriler ve/veya rakibe kaptırılmış olması muhtemel pasif müşteriler üzerine yoğunlaşılabilir. Bu sayede hızla gelişen dijital bankacılığa dair müşteri tutumlarının anlaşılmasına dair alanyazın geliştirilebilir.

\section{KAYNAKÇA}

Aksoy, L. (2007). Türkiye Bankacılık Sektöründe Çağrı Merkezleri ve Müşteri Memnuniyeti. Pazarlama Dünyası, Şubat.

Aktaş, A. (2019). Bankacılıkta Konuşma Sanatı ve Müşteri Deneyimi. Erişim adresi: https://www.genesys.com/tr-tr/blog/post/bankacilikta-konusma-sanati-ve-musterideneyimi

Altıntaş, M. H. (2000). Müşteri Tatmininden Müşteri Değerine, Tüketici Davranışları. Bursa: Alfa Yayınları.

Arı, E. and Yılmaz, V. (2015). Banka Hizmet Kalitesi Boyutları ile Banka Sadakati Arasındaki İlişkilerin Servqual ve Yapısal Eşitlik Modeli ile İncelenmesi: İ.İ.B.F Öğrencileri Üzerine Bir Uygulama. Süleyman Demirel Üniversitesi İ̈BF Dergisi, 20(3), 121-135.

Baytekin E. P. (2005). Toplam Kalite Hedefinde Müşteri Memnuniyetinden Müşteri Sadakatine. Ege Üniversitesi İletişim Fakültesi Yeni Düşünceler Hakemli E-Dergisi, 1, 41-52.

Bell, C. R. and Bell, B. R. (2004). Manyetik Servis: Müşteri Sadakati Yaratmanın Sırları. İstanbul: Elips Yayınları.

BKM (2020). Bankalararası Kart Merkezi - Tarihçe. Erişim adresi: https://bkm.com.tr/bkmhakkinda/bkmyi-taniyin/tarihce/

Chin, W. W. (1998). The Partial Least Squares Approach to Structural Equation Modeling. In G. A. Marcoulides (Ed.), Modern Methods for Business Research (pp. 295-336). New Jersey: Lawrence Erlbaum.

Choudhury, K. (2013). Service Quality and WOM (Word-of-Mouth): A Study of the Indian Banking Sector. International Journal of Customer Relationship Marketing and Management, 2, 6387. 10.4018/jcrmm.2011040105.

Del Bosque, I. R. and Martín, H. S. (2008). Tourist Satisfaction a Cognitive-affective Model. Annals of Tourism Research, 35(2), 551-573.

Diresehan, T. (2012). Müşteri Deneyimi Tasarımı ve Yönetimi. İstanbul: Hiperlink Yayınları.

DPT (2006). Bilgi Toplumu Stratejisi- Eylem Plant. Erişim adresi: ms.hmb.gov.tr/uploads/2019/01/Bilgi-Toplumu-Stratejisi-Eylem-Plani-2006-2010.pdf

Duffy, D. L. (1998). Customer Loyalty Strategies. Journal of Consumer Marketing, 15(5), 435-448. doi:10.1108/07363769810235910

Fornell, C. And Larcker, D. F. (1981). Evaluating Structural Equation Models with Unobservable Variables and Measurement Error. Journal of Marketing Research, 18(1), 39.

Garanti Ödeme Sistemleri (2020). Biz Kimiz. Erişim adresi: www.garantiodemesistemleri.com /tr/bizkimiz/garanti-bbvanin-urunleri/garanti-bbvadan-ilkler

Gronholdt, L., Martensen, A. and Kristensen, K. (2000). The Relationship Between Customer Satisfaction and Loyalty: Cross-industry Differences. Total Quality Management, 11(4-6), 509-514. doi:10.1080/09544120050007823

Hair, J. F., Hult, G. T. M., Ringle, C. M. and Sarstedt, M. (2014). A Primer on Partial Least Squares Structural Equation Modeling. Thousand Oaks: Sage.

Hair, J. F., Ringle, C. M. and Sarstedt, M. (2011). PLS-SEM: Indeed a Silver Bullet. The Journal of Marketing Theory and Practice, 19(2), 139-152. 
Harrison-Walker, L. J. (2001). The Measurement of Word-of-Mouth Communication and an Investigation of Service Quality and Customer Commitment As Potential Antecedents. Journal of Service Research, 4(1), 60-75. doi:10.1177/109467050141006

Hinson, R. E., Osarenkhoe, A. and Okoe, A. F. (2013). Determinants of Bank Selection: A Study of Undergraduate Students in the University of Ghana. Journal of Service Science and Management, 06(03), 197-205. doi:10.4236/jssm.2013.63021

Holbrook, M. B. and Hirschman, E. C. (1982). The Experiential Aspects of Consumption: Consumer Fantasies, Feelings, and Fun. Journal of Consumer Research, 9(2), 132. doi: $10.1086 / 208906$

Kandampully, J. and Suhartanto, D. (2000). Customer Loyalty in the Hotel Industry: The Role of Customer Satisfaction and Image. International Journal of Contemporary Hospitality Management, 12(6), 346-351. doi:10.1108/09596110010342559

Klaus, P. and Maclan, S. (2013). Towards a Better Measure of Customer. International Journal of Market Research, 55(2), 227-246.

Korkmaz, S. and Gövdeli, Y. E. (2005). Türk Bankacılığında Alternatif Dağıtım Kanalları ve Ürünleri ile Bunların Gelişiminde ve Pazarlanmasında Eğitimin Önemi. Endüstriyel Sanatlar Ĕgitim Fakültesi Dergisi, 15, 1-12.

Kurnia, S., Peng, F. and Liu, Y. R. (2010). Understanding the Adoption of Electronic Banking in China. In Proceedings of the 2010 43rd Hawaii International Conference on System Sciences (HICSS '10). IEEE Computer Society, USA, 1-10. doi:https://doi.org/10.1109/HICSS.2010.421

Lee, C.-K., Yoon, Y.-S. and Lee, S.-K. (2007). Investigating the Relationships among Perceived Value, Satisfaction, and Recommendations: The Case of the Korean DMZ. Tourism Management, 28(1), 204-214. doi:10.1016/j.tourman.2005.12.017

Lee, Ming-Chi. (2009). Factors Influencing the Adoption of Internet Banking: An Integration of TAM and TPB with Perceived Risk and Perceived Benefit. Electronic Commerce Research and Applications, 8, 130-141. 10.1016/j.elerap.2008.11.006.

Litvin, S. W., Goldsmith, R. E. and Pan, B. (2008). Electronic Word-of-mouth in Hospitality and Tourism Management. Tourism Management, 29(3), 458-468. doi:10.1016/j.tourman.2007.05.011

Neal, W. D. (1999). Satisfaction is Nice, But Value Drives Loyalty. Marketing Research, 11(1).

Oh, H. (2000). The Effect of Brand Class, Brand Awareness, and Price on Customer Value and Behavioral Intentions. Journal of Hospitality \& Tourism Research, 24(2), 136-162. doi:10.1177/109634800002400202

Oliver, R. L. (1997). Satisfaction: A Behavioral Perspective on the Consumer. NewYork: McGrawHill.

Onay, C. and Helvacioğlu, A. D. (2007). Internet Banking in the EU Harmonization Process: The Case of Turkey. Proceedings of 7th Global Conference on Business \& Economics, Rome, Italy.

Oyman, M. (2002). Müşteri Sadakati Sağlamada Sadakat Programlarının Önemi. Kurgu Dergisi, 19.

QNB Finansbank (2020). Hakkımızda. Erişim adresi: https://www.qnbfinansbank.com/qnbfinansbanki-taniyin/hakkimizda

Rust, R. T. and Zahorik, A. J. (1993). Customer Satisfaction, Customer Retention, and Market Share. Journal of Retailing, 69(2), 193-215. doi:10.1016/0022-4359(93)90003-2

Savaş, Ö., Molu, F., Atlı, M. ve Yazıcı, H. (2014). Bankacılık Sektöründe Kullanıcı Deneyimi Araştırması: Dijital Şube, XTM. XVI. Akademik Bilişsim Konferansı Bildirileri, Mersin: Mersin Üniversitesi, s. 173-185. https://ab.org.tr/kitap/ab14.pdf

Shaw, C. and Ivens, J. (2002). Building Great Customer Experiences (Beyond Philosophy). NewYork: Palgrave Macmillan.

Sipahi, B., Yurtkoru, E. S. ve Çinko, M. (2008). Sosyal bilimlerde SPSS'le veri analizi.İstanbul: Beta Basım Yayım Dağıtım.

Subaş1, Ö. (2018, Haziran). Dijital Bankacılık Alanında Müşteri Deneyimi. Erişim adresi: httpsozgesubasi.wordpress.com/2018/06/22/dijital-bankacilik-alaninda-musteri-deneyimi/

Takan, M. (2001). Bankacılık. Nobel Yayınevi, Ankara. 
Tan, A., İgde, M., Çelik, T. Z. ve Buğan, M. F. (2016). Algılanan Hizmet Kalitesinin Katılım ve Mevduat Bankalarında Müşteri Memnuniyeti ve Müşteri Sadakati Üzerine Etkisi. International Journal of Academic Value Studies, 2(5), 45-59.

TBB (2012, Şubat). Türkiye'de Bankacılık Sektörü Piyasa Yapısı, Firma Davranışları ve Rekabet Analizi. Erişim adresi: www.tbb.org.tr/Content/Upload/Dokuman/796/rekabetKitap.pdf

TBB (2020). Ístatistiki Raporlar. Erişim adresi: https://www.tbb.org.tr/tr/bankacilik/banka-ve-sektorbilgileri/istatistiki-raporlar/59

Türkiye İş Bankası (2020). İlklerimiz. Erişim adresi: https://www.isbank.com.tr/bankamizitaniyin/ilklerimiz

Yoon, C. (2010). Antecedents of Customer Satisfaction with Online Banking in China: The Effects of Experience. Computers in Human Behavior, 26. 1296-1304. 10.1016/j.chb.2010.04.001.

Yurttadur, M. ve Süzen, E. (2016). Türkiye'de Banka Müşterilerinin İnternet Bankacılığına Yaklaşımlarının İncelenmesi Üzerine Bir Uygulama. Tüketici ve Tüketim Araştırmaları Dergisi, 8(1), 93-120.

Walls, A. R., Okumus, F., Wang, Y. and Kwun, D. J.-W. (2011). An Epistemological View of Consumer Experiences. International Journal of Hospitality Management, 30(1), 10-21. doi:10.1016/j.ijhm.2010.03.008

Wang, Y. and Tang, T. (2004). A Validation of the Customer Information Satisfaction Instrument for Digital Market Context. International Journal of Electronic Business, 2(6), 567-582.

Westbrook, R. A. (1987). Product/Consumption-Based Affective Responses and Postpurchase Processes. Journal of Marketing Research, 24(3), 258. doi:10.2307/3151636

\section{Ek 1}

\begin{tabular}{|c|c|}
\hline & (Bu bankanın dijital bankacılık uygulaması ...) \\
\hline KUL1 & ...nda aradığım işlemlere menülerde ulaşmak kolaydır. \\
\hline KUL2 & ... işlem süreci kolaylığına sahiptir. \\
\hline KUL3 & ... kolay bir sorgulama prosedürüne sahiptir. \\
\hline KUL4 & ..., kullanımı kolay bir web tasarımına sahiptir. \\
\hline KUL5 & $\begin{array}{l}\text { Bankacılık görevlerimi yerine getirmek için ...nı kullanmanın kolay olduğunu } \\
\text { düşünüyorum. }\end{array}$ \\
\hline KOL1 & ...nı kullanmamın görevlerimi yapmamı kolaylaştıracağını düşünüyorum. \\
\hline KOL2 & ...nın faydalı olduğunu düşünüyorum. \\
\hline KOL3 & ...nı kullanarak bankacılık işlemlerimde zaman kazanabileceğini düşünüyorum. \\
\hline KOL4 & $\begin{array}{l}\text {...nı kullanmanın bana daha geniş bir bankacılık ürünleri, hizmetleri ve yatırım firsatları } \\
\text { sunabileceğini düşünüyorum. }\end{array}$ \\
\hline KOL5 & $\begin{array}{l}\text {...nı kullanmanın bankacılık işlemlerini gerçekleştirirken işlem masraflarını azaltabileceğini } \\
\text { düşünüyorum. }\end{array}$ \\
\hline KOL6 & Genel olarak, ...nı kullanmanın avantajlı olduğunu düşünüyorum. \\
\hline GUV1 & ... kişisel bilgilerimi ifşa etmeyecektir. \\
\hline GUV2 & Bankacılık işlemlerini yürütmede ...nı güvenli buluyorum. \\
\hline GUV3 & ...nın sunucuları iyi performans gösteriyor ve ödemeleri doğru bir şekilde yapıyor. \\
\hline GUV4 & ...nda işlem hataları meydana geldiğinde bankamdan tazminat alabileceğime inanıyorum. \\
\hline GUV5 & ... üzerinden kişisel gizlilik bilgisi sağlama konusunda kendimi güvende hissediyorum. \\
\hline GUV6 & ...nı kullanmaktan endişelenmiyorum, çünkü diğer insanlar hesabıma erişemeyecektir. \\
\hline BIL1 & ...nın bilgi içeriği yararlıdır. \\
\hline BIL2 & ..., konuyla ilgili bilgi içeriği sağlamaktadır. \\
\hline BIL3 & ... güncel bilgi içeriği sağlamaktadır. \\
\hline BIL4 & ...nın bilgi içeriği kolayca anlaşılmaktadır. \\
\hline HIZ1 & ...nın bağlantı süresi hızlıdır. \\
\hline HIZ2 & ...nda işlem süreci hızlıdır. \\
\hline HIZ3 & ...nın sayfa yükleme süresi hızlıdır. \\
\hline HIZ4 & ... işlem gereksinimlerime çok hızlı çözümler sunuyor. \\
\hline
\end{tabular}


DES1 ... müşterinin taleplerine tam olarak cevap vermektedir.

DES2 ... sorun hakkında derhal geri bildirim sağlamaktadır.

DES3 ..., müşterinin sorunlarını ve memnuniyetsizliğini ele almaya ve çözmeye hazır durumdadır.

Müşteri Sadakati Ölçeği $\quad$ (Bu bankanın dijital bankacılık...)

sad1 ... uygulaması hakkında başkalarına olumlu şeyler söylerim.

sad2 Arkadaşlarımı ve akrabalarımı ... uygulamasını kullanmaya teşvik ederim.

sad3 ... hizmetlerini ilk seçenek olarak düşünürüm.

sad4 Tavsiyemi isteyen birine ... hizmetlerini öneririm.

sad5 ... hizmetlerini önümüzdeki birkaç yıl içinde kullanmaya devam edeceğim.

tat1 ... hizmetleri ile ilgili hislerim çok olumludur.

tat2 Aradığım teklifler için ...nı kullanırken kendimi iyi hissediyorum.

tat3 Genel olarak ... hizmetlerinden memnunum.

tat4 ... hizmetlerinin benim için ulaşılabilecek en iyi sonuçları üretmesinden memnunum.

tat5 ... hizmetleri benim için mümkün olan en iyi sonucu üretme konusunda tatmin edicidir.

Tavsiye Eğilimi Ölçeği (Bu bankanın dijital bankacılık...)

tav1 ... uygulamaları ile iş yaptığım hakkında başkalarına bahsederim.

tav2 Başkalarının ... uygulamalarıyla iş yaptığımı bilmesini isterim.

tav3 ... hizmetlerini sunan kişilerle ilgili başkalarıyla olumlu konuşurum.

tav4 ... hizmetlerini aileme öneririm.

tav5 ... hizmetleri hakkında diğer kişilerle olumlu konuşurum.

tav6 ... hizmetlerini tanıdıklarıma öneririm.

tav7 ... hizmetlerini kişisel arkadaşlarıma öneririm.

\section{SUMMARY}

The rapid development of digital technologies has led businesses in all industries to evaluate their own situations and futures, to understand the change in market conditions, and to update their basic strategies. In the banking sector, the use of technologies that have become widespread, primarily to improve internal operational processes, has subsequently expanded towards the redesign of products and services offered to customers, access to customers, and further customer acquisition efforts. The rapid adoption of digital technologies by customers has made digital transformation an inevitable journey for all businesses.

Creating a positive customer experience in today's competitive environment is related to customer retention and appealing new ones. Banks, like all other enterprises, have attempted to differentiate in terms of experience to be ahead of the competition. Due to the rapid adoption of smart devices and broadband / mobile internet access by all customer groups, banks have turned to provide services through digital channels. Thus, each computer and smartphone has become a bank branch for customers. Although digital applications bring fast and easy processes, they reduce the one-to-one relationship between the customer and the bank employees. Understanding this change in customer experience and its effects on customer attitudes will be an important gain for businesses in a highly competitive market such as banking.

This study examines the reflections of the digital transformation in the banking sector and the changing customer experience on the attitudes of customers, such as loyalty, satisfaction, and tendency to recommend. Within the scope of the research, the data were obtained from digital banking customers by survey method. 
The research sample is aimed to represent Turkish bank customers who use digital applications, and out of a convenience sampling method, 364 responses were reached in total. A specific bank and its digital application were not determined for the research, in contrast, individuals using the digital applications of all banks were covered. During the preparation of the measurement form, the literature was reviewed and scales that were found valid and reliable in previous studies were determined and adapted to the study. Partial Least Squares Structural Equation Model (PLS-SEM) method was preferred for the analysis of the data collected within the scope of the research. Smart PLS 2, one of the programs developed for this purpose, was used.

The results of this research coincide with the studies in the literature to a certain extent and differ in some respects. When the research results are evaluated regarding the customer experience, it is understood that the customers do not perceive a significant difference between the digital banking experience in terms of speed, customer support, security, and information content. It was understood that the banks operating within the framework of the laws, regulations, and related authorities offer the same technology and products, and they are perceived as indifferent to the customer in these dimensions.

The remarkable results of the study is the emphasis placed on the ease of use and usefulness of the digital applications. Customer satisfaction and customer loyalty to the bank are found to be determined by these two features. Therefore, it is important for the banks to focus on user-friendliness such as providing easy navigation in their digital applications, ensuring that transactions can be found easily and completed hassle-free. 